\title{
SOME PROSPECTIVE DIRECTIONS OF EFFECTIVE DEVELOPMENT OF THE ECONOMY OF NAVOI REGION
}

\author{
Isabek B. Murtazaev \\ Department of Economics \\ National University of Uzbekistan named after Mirzo Ulugbek \\ 100174, 4 University Street Str., Tashkent, Republic of Uzbekistan \\ isabekmurtazayev777@mail.ru
}

\section{Nilufar Kh. Komilova}

Department of Economic and Social Geography

National University of Uzbekistan named after Mirzo Ulugbek

100174, 4 Universitet Ko'chasi Str., Tashkent, Republic of Uzbekistan

nkomilova75@mail.ru

\section{Iroda A. Khudoyberdiyeva,}

Department of Economic and Social Geography

Navoi State Pedagogical Institute

210100, 45 Ibn Sino Str., Navoi, Republic of Uzbekistan

Email: irodandpi@gmail.com

\section{Zulxumor A. Abdieva}

Department of Economic and Social Geography

Navoiy State Pedagogical Institute

210100, 45 Ibn Sina Str., Navoiy, Republic of Uzbekistan

abdievazulxumor5@gmail.com

\begin{abstract}
This article examines the specific features and problems of economic development of Navoi region. It is known that today a "completely new system of rapid economic development of the regions of the republic, including the organization of the effective use of their natural, economic and human potential" has been introduced. This system is implemented on the principle of "neighborhood - district (city) - region - republic." It requires the development of targeted practical measures for the development of the region, taking into account the specifics of the regions and the level of development. This is because the location of the productive forces of the regions differs from each other by their natural and economic potential. In particular, research aimed at ensuring the sustainable development of Navoi region, which is of strategic importance in the country, improving the living standards of the population, increasing production and export potential, effective use of natural and economic potential is of great importance. The article assesses the current state of specialization of the economy of the districts of Navoi region and develops recommendations for future specialization through the effective use of existing opportunities;

Keywords: Region, natural and economic potential, sectors of the economy, specialization, economic system, animal husbandry, astrakhan, pasture, ground water.
\end{abstract}

Article Received: 18 October 2020, Revised: 3 November 2020, Accepted: 24 December 2020

\section{Introduction}

Today, the scope of scientific research on the economic development of the regions is expanding. This work differs from other similar works in that it is a study of the specific directions of development of Navoi region, which has a rich natural and economic potential, with a comprehensive link between the sectors and regional structure of the economy.
Navoi region is located in the central and northern part of Uzbekistan, and in 1982 it was formed from the lands of Bukhara region and partly Samarkand region. The province was abolished as an administrative unit in 1988 and re-established in early 1992. It includes 8 rural districts (Konimex, Navbahor, Karmana, Nurata, Tomdi, Uchkuduk, Khatirchi, Kyzyltepa), 6 cities (Navoi, Zarafshan, Karmana, Nurata, Uchkuduk, 
Kyzyltepa) and 47 settlements, 571 rural settlements. enters ${ }^{1}$.

The area of the region is 110.99 thousand square meters.km $(24.7 \%$ of the territory of the Republic). In particular, Uchkuduk (46.6 thousand sq. Km.) And Tomdi (42.5 thousand sq. Km.) Districts are very large. The large size of these rural districts indicates that the area does not have favorable conditions for agriculture and settlement. The area of the remaining districts is much smaller (the smallest is Karmana district - 0.95 thousand sq. Km).

$91.5 \%$ of the total land area of the region is pastures and hayfields, $1 \%$ is arable land, $0.4 \%$ is perennial trees and $7.1 \%$ is non-agricultural land. In general, the fact that the territory of Navoi region stretches from north to south for a long time, its developed areas, as well as the administrative center in the far south, creates inconveniences in the organization and management of economic development of the region.

The region differs sharply from other regions of the republic in its orographic features. The small remnant mountains in its territory are rich in various mineral resources. It is these mineral resources that play an important role in shaping the regional economy, developing its production and export potential.

The regional climate does not create favorable conditions for the development of agriculture, in particular, its farming network. Therefore, Navoi region specializes mainly in desert pasture, karakul.

The demographic potential of Navoi region is small. The population at the beginning of 2019

${ }^{1}$ Komilova, N.Kh., Hudayberganova, R.T, Murtazaev, I.B., Abdinazarova, H.O., \& Madaminov, Z.H. (2019). Economic and Geographic Problems of Improvement of Industrial Sectors and Local Structure of Uzbekistan. Journal of Advanced Research in Law and Economics, 10( 6 (44)), 1916-1928. was 974.3 thousand people $(3.0 \%$ of the population). In terms of demographic potential, the region is ahead of the Syrdarya region. The population of the region increased by $14.2 \%$ in 2010-2019, the increase in population was mainly due to natural growth.

The region has the lowest population density compared to other regions of the country (8.8 people per 1 sq. Km). Especially in Tomdi and Uchkuduk districts, where water resources are scarce and desert, the population density is less than 1 person per $1 \mathrm{sq}$. Km. The density is also very low in Konimex district (3.3 people). The highest population density is in Zarafshan (3868.1 people) and Navoi (2646.6 people). Among the districts, Khatirchi (137.7 people) and Karmana (134.0 people) have the highest population density (2019).

The population of the region is very unevenly distributed in the interior. In particular, $14.1 \%$ in the city of Navoi, as well as Khatirchi (20.0\%), Kyzyltepa (15.3\%), Karmana (12.9\%), Navbahor $(11.3 \%)$ and Nurata $(9.3 \%)$. more concentrated in the districts.

The share of Navoi region in the total number of people employed in the economy of the country is $3.2 \%$ and is the last in the country in terms of employment. The main part of the employed population by industry is engaged in industry (27.0\%) and agriculture (22.3\%).

At the beginning of 2019, the number of registered business entities in Navoi region amounted to 11,281 . There were 11.5 business entities per 1,000 people. $3.3 \%$ of the existing business entities in the country are located in the region. $95.0 \%$ of all enterprises and organizations in the region belong to the non-governmental sector of the economy.

$24.3 \%$ of registered businesses are located in Navoi. Among the districts, Khatirchi, Karmana and Qiziltepa are the leaders in this regard.

According to the analysis of statistical data, more than half of the registered economic entities in Navoi region $(54.6 \%)$ are in agriculture and 
forestry. Also, a large figure was formed in industry and construction.

The regional economy is mainly specialized in industry, which determines the level of economic development of the region and the country

plays an important role in determining the location. It should be noted that Navoi region specializes in the most important and unique "strategic" industries for our country. There are a total of 799 industrial enterprises in the region, of which 21 are large and the rest are small industrial enterprises. Most of these enterprises are operating at 65-70 percent capacity, because the fixed assets, as well as equipment in many enterprises are obsolete, both materially and spiritually. As a result, they require renewal, modernization and reconstruction ${ }^{2}$.

The core of the industrial potential of Navoi region is the mining industry, which accounts for $56.5 \%$ of total industrial output. The basis of the economy is the extractive industries, which supply raw materials for the non-ferrous metallurgy, chemical industry, construction materials and energy industries, which are considered valuable in the world market. The leading objects of industrial production in the region are Navoi Thermal Power Plant $(8.9 \%$ of total industrial production), Navoi Mining and Metallurgical Complex (60\%), Navoiazot (7.5\%), Kyzylkumtsement (11.2\%). enterprises, which account for more than $85 \%$ of the total output. The dynamics of the development of these important enterprises affects not only the economy of the region, but also the economy of the whole republic.

It is known that agriculture, a major sector of the economy, is not well developed in Navoi region. The main reasons for this are the typical desert

${ }^{2}$ Komilova, N. K., Haydarova, Ş. A., Xalmirzaev, A. A., Kurbanov, S. B., \& Rajabov, F. T. (2019). Territorial Structure of Agriculture Development in Uzbekistan in Terms of Economical Geography. Journal of Advanced Research in Law and Economics, 10(8 (46)), 2364-2372. areas of the region, the extremely scarcity of agroclimatic resources, the poor development of the soil layer, the lack of moisture.

In recent years, as a result of optimizing the structure of arable land, cotton fields have been reduced due to low-yielding and low-yielding lands. Fruits and vegetables were planted on the vacant lands on the basis of the introduction of new advanced agro-technologies, including the construction and reconstruction of new intensive orchards, vineyards and greenhouses.

It should be noted that according to the classification of soil quality in the region, 33.3\% of the total arable land is good, $39.5 \%$ is average and the remaining $27.2 \%$ is below average and of poor quality. The land quality score in the region is 52 points, including 46 points in Konimex and Karmana districts, 51 points in Nurata district, 52 points in Navbahor district and 59 points in Khatirchi district ${ }^{3}$.

$26.5 \%$ of irrigated lands are eroded and saline, of which $6.9 \%$ are strongly saline and $19.6 \%$ are moderately saline. Therefore, it is necessary to rehabilitate existing irrigation networks in the region, build new water facilities and increase their efficiency. According to the analysis of statistical data, the share of cotton in the level of processing of agricultural products in the region is $100.0 \%$, and the share of grain is $95.0 \%$. In recent years, much attention has been paid to the processing of more than half of all types of agricultural products grown in the region.

It is known that the increase in agricultural production also has a positive impact on the growth of industrial potential of the region and is a food raw material for growing industrial workers. Its arable land is much smaller than the size of the region. The total sown area here is only 109.2 thousand hectares. This is $2.7 \%$ of the country's arable land. In $2017,45 \%$ of the total sown area

\footnotetext{
${ }^{3}$ Murtazaev I.B. On the issue of developing a strategy for the socio-economic development of the Navoi region // Economy and entrepreneurship. No. 12. Moscow, 2017. -S. 324-326.
} 
was planted with cereals and legumes, and $36.3 \%$ with cotton.

According to statistics, the level of supply of agricultural products to the population of the region is not at the level of demand for flour, vegetable oil, potatoes and eggs, which are needed for daily needs. However, the population is highly supplied with meat, milk, vegetables, melons, fruits, and grapes.

Grain, cotton and vegetable growing are the leading industries in the region. The region ranks low among the regions of the republic in terms of grain and cotton yields. At the same time, agricultural sectors such as fruit and vegetable growing, melon growing and viticulture are also developing in the region. In recent years, much attention has been paid to the cultivation of almonds in the foothills.

Intensive pistachio plantations have been started on 1,000 hectares of arable land in the mountainous and foothill areas of the Nurata district of the region. As a result of the launch of this plantation, 850 people have been provided with permanent jobs.

It is known that pistachios, grown in mountainous and foothill areas are distinguished by their pleasant taste. Scientists have determined that the pistachio tree can bear fruit for up to a thousand years. It is planned to build new plantations on the basis of advanced technologies. Pistachios planted on the basis of this technology will be harvested in 7-8 years. The pistachio plantation will be established in 2018-2021.

It is expedient to build a garden and modern greenhouses in Khatirchi district, to process fruits and vegetables, to create almond and pistachio plantations in Navbahor district using drip irrigation, to pay special attention to the breeding of karakul and goat wool.

The second largest branch of agriculture is animal husbandry, which specializes mainly in the production of meat and dairy products. Navoi region ranks relatively low in terms of meat and dairy production in the country.
It should be noted that in areas specializing in animal husbandry, it is desirable to have a sufficient fodder base. However, in Navoi region, mainly pastoral livestock is developed, and fodder crops are grown on 7.5-8.0 thousand hectares. Alfalfa and corn are grown for fodder ${ }^{4}$.

The desert zones of the region specialize in karakul farming. The region accounts for more than $30 \%$ of the country's karakul production and is second only to Bukhara region. In recent years, the country has produced an average of more than one million astrakhan skins a year.

It is known that karakul sheep have a unique feature that is suitable for grazing in pastures all year round. However, the current condition of arid pastures does not meet the requirements for full grazing of livestock. Due to the intensive use of natural resources in recent years, especially the irregular use of natural pastures for livestock grazing the sector is facing great challenges. This, in turn, leads to a decrease in the grassy nutrient layer of the soil, changes in biodiversity composition, a decrease in soil fertility, and the emergence of a desertification process. Given that livestock is the main source of sustainability and livelihoods of the people living in these areas, these processes not only pose a threat to biodiversity, but also lead to a decline in the living standards of the local population. It should be noted that irregular feeding of livestock leads to the destruction of vegetation, which leads to a crisis of pastures and a decrease in productivity. Especially in Navoi region, pasture productivity decreased by $42-43 \%$. Historical data show that in the past, grazing in the desert pastures was done by semi-nomadic methods and frequent rotation of pastures. Because of this, the pastures would recover. Nowadays, for the most part, livestock, especially near wells and around local settlements. Regularly grazed, which has led to overuse of

\footnotetext{
${ }^{4}$ Murtazaev I.B.(2018) The question of development of the strategy for socio economic development of the Navoi region. European journal of economics and Management Sciences. №3. 36-40.
} 
pastures, extending settlements by several square kilometers. In these areas, overuse of pastures can lead to complete degradation of vegetation.

Today, farms are the main producers in animal husbandry, accounting for $97 \%$ of the gross output of the entire industry. The increase in the production and income of karakul production, profitability and the stability of the industry development depend on the state of the fodder base, the efficiency of fodder production technologies, the organization of production on the basis of scientific innovations and best practices $^{5}$.

In terms of agro-climatic conditions of the region and the associated territorial organization of agriculture, in our study we divided the region into three agro-economic regions:

Lower agro-economic region, which includes the city of Navoi, Karmana, Khatirchi, Nurata, Navbahor and Kyzyltepa districts, Although small in area, the regional concentration of production is high. The suburban economy, the majority of agricultural products grown in the region falls on the share of this region. In particular, most of the fruits and vegetables are grown in Khatirchi, Kyzyltepa, Karmana and Navbahor districts. Khatirchi district, which is part of this region, also stands out in terms of fruit growing and the number of cattle. Kyzyltepa district is one of the leading producers of fisheries, poultry, meat and meat products in the region.

Middle agro-economic region - it includes Konimex district. The peculiarity of the location of the district can be the basis for its acquisition as a separate district. The center of this district is in the south, and the main area is in the north,

Komilova, N.Kh., Mukhammedova, N.J., Abdalova, Z.T., Nazarov, M.I., \& Kurbanov, P.R.(2020). Separate aspects of the demographic situation in Uzbekistan and its assessment in geographical context. International Journal of Psychosocial Rehabilitation. 24(08) 6773-6792. disconnected. The district is a leader in the region in the field of karakul (83469 units).

It is a high agro-economic region, which includes two large districts, Tomdi and Uchkuduk, which occupy desert areas. The population is sparse, production is located in the form of separate "centers". Here, the area specializes in desert pastoralism and mining.

Although all three agro-economic regions have their own specialization sectors, it is recommended that the following measures be taken or further strengthened in these areas in the future: 10(8 (46)), 2364-2372.

Construction of gardens and greenhouses in Khatirchi district, small fruit and vegetable processing enterprises, creation of drip irrigation almond and pistachio plantations in Navbahor district, establishment of poultry and fish farms in Karmana and Kyzyltepa districts. It is expedient to further strengthen the activities of research centers, to establish special enterprises specializing in seed production in the districts;

Due to the geographical location of Konimex district, which is part of the middle agro-economic region, it is desirable to establish small agricultural processing enterprises in the south, ie in the center of the district, as well as more karakul, tivit wool and camel breeding in the northern part ${ }^{6}$.

The territory of the Upper Agro-Economic Zone is characterized by a large area, sparse population, but also by many sectors of agriculture. It is necessary to build a cattle-breeding complex for karakul, camel and goat breeding in these districts, and to establish specialized enterprises in these districts that process wool and leather and turn them into finished products.

${ }^{6}$ Komilova, N.K., Mukhammedova, N.J., TOJIEVA, Z.N., Nazarov, M.I., \& Egamberdiyeva, U.T.(2019) Territorial Definitions of Population Mortality in Uzbekistan ASTRA SALVENSIS, YEAR VII, Supplement no. 1, 619-641 
In general, the following practical recommendations for the further development of agriculture in the region are useful:

comprehensive modernization of the agricultural sector in the region, their development with deep use of scientific and technical achievements, implementation of measures aimed at the introduction of modern and intensive resourcesaving agro-technologies, advanced foreign experience;

proper feeding and maintenance of livestock in natural pastures, compliance with the load of grass and its normal capacity, the use of alternative, cheaper and more convenient technologies in the preparation of fodder in the conditions of farms specializing in karakul;

- $\quad$ increase the export potential of sectors of the economy through the production of competitive products, conduct market research on market conditions and attract foreign investment;

- organization of the formation of agricultural and food stocks that provide the population of the region throughout the year;

- consistent and sustainable development of agriculture in the region, increase employment and income of the population not only through the cultivation of agricultural products but also the strengthening of their processing industry. The above proposals and recommendations will further contribute to the socio-economic development of the region.

In this study, the role of Navoi region in the specialization of the agricultural sector in the regions of the country was analyzed and certain results were achieved.

Due to the fact that data on agricultural production are presented in kind, rather than in terms of value by region, in contrast to the industrial and service sectors, a specific method is used. This will determine the specialization of production of 14 types of basic agricultural products.

As can be seen from Table 1, the level of specialization in agricultural production in the country was determined in 159 districts. The peculiarity of determining the specialization in agricultural production is that if it were assumed that all types of products are available in equal quantities in all districts, their ratio would be $0.62 \%$ (100\%: 161 districts $=0.621 \%$ ). The 0.621 index determined in this way serves as the basis for determining the level of specialization.

Therefore, an indicator greater than $0.62-1.0$ per cent - was chosen as the conditional indicator, indicating specialization, as an expression of the leading industry indicator. That is, it was assumed that districts with a share of 1 percent or more relative to the national average specialize in the production of certain types of products. A score below 1,000 is an indication of a lack of specialization. This method is the most effective and convenient in determining the regional specialization of agricultural production through in-kind indicators.

The study found that the cultivation of grapes (62.8\%), cocoons $(52.2 \%)$, fish $(58.2 \%)$, wool (54.4\%) and especially astrakhan leather (93.1\%) was concentrated in certain areas. At the same time, regional specialization in the production of products such as meat, milk and grain is low, on the contrary, they have a high degree of diversification (Table 1). The results of the study showed that the specialization in the production of agricultural products varies greatly by region.

The highest rates in this area, ie specialization in the production of 9 types of products were recorded in Gijduvan (Bukhara region), Khatirchi (Navoi region) and Pastdargom (Samarkand region) districts. At the same time, it was found that 36 rural districts of the country do not specialize in any type of product. The main part of them falls on the Republic of Karakalpakstan (11) and Fergana (7) regions. The reason for this is due to several factors.

Unfavorable environmental conditions in the Aral Sea region, strong salinization of lands have a negative impact on the development of the agricultural sector in Karakalpakstan. The level of diversification is high in the districts of Fergana region. In other words, Fergana region ranks 6th 
in the country in terms of agricultural production (8.3\%) and almost all types of products are grown in all regions. This, in turn, hinders the region's deep specialization in any type of product. In the future, there is an opportunity to further deepen the specialization of agricultural production through the efficient use of available resources in the regions. To this end, the following factors were taken into account in the research:

- The level of land resources of the district and the quality of land (agricultural area - to, land productivity - points);

- The level of water supply of the district (water supply, the ratio of water used in practice and demand);

provision of the district with forest resources (forest areas larger than 5,000 hectares);

- Opportunities to export fruits and vegetables (proximity to highways and logistics centers);

- Possibilities of application of modern and economical methods of irrigation (drip, etc.);

- Possibilities of strengthening selection work on livestock breeds and plant varieties and their application in the production of positive results.

In the next stage, the state of sectoral specialization of each district was thoroughly analyzed in order to prioritize the production capacity and use it in the socio-economic development of the regions. Based on these indicators, it was determined that in the future each district should specialize in certain types of industry, agriculture and services. The existing mineral resources, land, water, agricultural resources, production and export potential, environmental and other conditions of the regions were taken into account.

From the current specialization of the districts, it is determined whether any type of activity will remain in the future. The types of activities to be maintained are listed in the "Recommendations for future specialization" section of the table. After all, due to the favorable climate, land, water, labor skills, raw materials and other conditions in a particular place, it would be right to maintain the type of activity that has been successfully carried out for a long time. New types of activities recommended for the specialization of the district are also included in this section of the table and are given in dark black to stand out.

It is known that sheep-breeding and goat-breeding are an integral part of the country's economy, which meets the needs of the population in traditional raw materials and food products in some areas with relatively harsh climatic conditions. 
The structure of land areas of districts and cities of Navoi region

\begin{tabular}{|c|c|c|c|c|c|c|c|c|c|c|}
\hline \multirow[t]{2}{*}{$\begin{array}{lr}\text { Name } & \text { of } \\
\text { district } & \text { and } \\
\text { city } & \end{array}$} & \multirow[t]{2}{*}{$\begin{array}{l}\text { Total } \\
\text { land } \\
\text { area }\end{array}$} & \multicolumn{8}{|l|}{ Including: } & \multirow[t]{2}{*}{$\begin{array}{l}\text { The share of } \\
\text { hayfields and } \\
\text { pastures in total } \\
\text { agricultural land }\end{array}$} \\
\hline & & $\begin{array}{l}\text { Cultivated } \\
\text { lands }\end{array}$ & $\begin{array}{l}\text { Perennial } \\
\text { trees }\end{array}$ & $\begin{array}{l}\text { Gray } \\
\text { lands }\end{array}$ & $\begin{array}{l}\text { Hay and } \\
\text { pastures }\end{array}$ & $\begin{array}{l}\text { Types of } \\
\text { agricultural } \\
\text { land }\end{array}$ & $\begin{array}{l}\text { Lands of } \\
\text { garden, } \\
\text { horticultural } \\
\text { and } \\
\text { vegetable } \\
\text { associations }\end{array}$ & Forests & $\begin{array}{l}\text { Non- } \\
\text { agricultural } \\
\text { lands }\end{array}$ & \\
\hline Regions & 100,0 & 1,0 & 0,09 & 0,06 & 78,7 & 79,9 & 0,2 & 11,4 & 7,3 & 98,5 \\
\hline \multicolumn{11}{|l|}{ Including: } \\
\hline Navoi & 100,0 & 1,0 & & & & 1,0 & & & 99,0 & \\
\hline Nurota & 100,0 & 2,9 & 0,2 & & 73,4 & 76,5 & 0,5 & 0,5 & 22,6 & 96,0 \\
\hline Tomdi & 100,0 & 0,01 & & & 84,2 & 84,2 & 0,01 & 11,7 & 4,1 & 99,992 \\
\hline Uchkuduk & 100,0 & 0,003 & & & 79,3 & 79,3 & 0,002 & 12,4 & 5,2 & 99,997 \\
\hline Khatirchi & 100,0 & 20,9 & 3,1 & 0,6 & 50,9 & 75,5 & 5,0 & 0,4 & 19,1 & 67,4 \\
\hline Kiziltepa & 100,0 & 10,3 & 1,0 & 2,0 & 56,6 & 70,0 & 1,7 & 1,1 & 27,2 & 80,9 \\
\hline
\end{tabular}

Source: Author's calculations based on the data of the Department of Land Resources and State Cadastre of Navoi region 
This industry is the main source of products such as wool, meat, astrakhan leather, fur, milk, leather and felt. The organization of livestock in the desert area is not only financially beneficial, but also important for the desert soil layer and flora. Livestock helps to absorb more water by breaking down the crust on the soil surface, which ensures the re-emergence of desert plants, and they scatter plant seeds throughout the desert, thus helping to slow down the desertification process. However, their overpopulation also causes certain problems (shrinkage of the desert gene pool, increased sand movement and erosion, escalation of the desertification process, etc.).

The natural and climatic conditions of the Navoi region, where the study is being conducted, allow for the development of pastoral livestock, in particular, sheep and goats. A very large part of the region's territory consists of deserts, with $98.5 \%$ of the total agricultural land area being pastures and hayfields. In Konimex, Tomdi, Uchkuduk districts this figure is almost one hundred percent (Table 1).

Despite the fact that the area is very large, the growing season is very short for the growth of plants in desert pastures due to unfavorable natural-climatic conditions, especially water scarcity (the growing season in this area coincides with early spring, precipitation).

The biggest problem in the growth of fodder plants needed for livestock is water scarcity, and the tried and tested and most acceptable way to solve this problem is to dig wells to organize livestock irrigation in hayfields and pastures.

At present, in order to develop pastoralism in some mountainous, steppe and desert regions of the country, new wells are being dug systematically. In particular, it is necessary to remember the work being done in Karakul district of Bukhara region, Zaamin district of Jizzakh region and the Republic of Karakalpakstan. In this regard, it is expedient to implement these measures in the desert areas of Navoi region.

Therefore, the study analyzed data on the state of groundwater (data of the Institute of Hydrology and Engineering Geology and the Kyzylkum Hydrogeological Station) in order to further develop livestock in the desert region of Navoi region, and the following results were obtained.

There are 20 potential underground water deposits in Navoi region, 16 of which are located in the desert and the remaining 4 in the irrigated areas.

In the desert area there are such subsoils as Western Kashkadarya, Karagota, Tashqura, Kyzylkok, central Kyzylkum massif, Ukuzkak, Tubelek, Tomdibulak, Mingbulak, South - Aral Sea, Buzakboy, East Kyzylkum, North - East Kyzylkum and Nurata.

It should be noted that in these areas, the intermediate from the ground level to the groundwater table consists of sandstones, limestones and claystones.

Depth of groundwater withdrawal is from $50 \mathrm{~m}$ to $150 \mathrm{~m}$, diameter of pipes during the observation period is $89 \mathrm{~mm}$. and $152 \mathrm{~mm}$. The average water intake of the pumps ranged from 2.55 thousand $\mathrm{m} 3$ to 4.90 thousand $\mathrm{m} 3$ per day.

Of the total number of observation wells (104), $34.8 \%$ were drawn from one hundred meters and $65.2 \%$ from one hundred and less meters. Regional groundwater reserves as of 01.01.2014. as of 1853.25 thousand $\mathrm{m} 3$ / k.k. formed; including explored and proven reserves 1222.1 thousand $\mathrm{m} 3$ / k.k. formed[7].

The above data from the GIDROINGEO Institute and the Kyzylkum Hydrogeological Station confirm the potential for livestock, karakul and cattle breeding in the desert areas of Navoi region. This will allow the region to further develop this sector in the future.

It should be noted that karakul sheep are characterized by their adaptability to the desert climate, ie, resistance to drought, regular movement in the desert pastures in all seasons of the year. Exactly karakul sheep are extremely suitable for the desert areas under study. Research has been conducted in Tomdi and Uchkuduk districts in order to conduct research on the accelerated development of animal husbandry, 
including karakul, in the economic development of the region.

It is known that Tomdi and Uchkuduk districts together make up $80 \%$ of the region's area $(89.12$ thousand sq. Km.).

According to the data for 2019-2020, there are 385.2 thousand sheep and goats, 7.6 thousand cattle, 8.4 thousand horses and 4.6 thousand camels in these districts, which account for $11 \%$ of meat production in the region, $1 \%$ of dairy products. $8 \%$, karakul leather $28.5 \%$, sheared wool $22.6 \%$ (Table 2)

Research shows that Navoi region is not able to fully use its natural resources. In particular, today the total number of ungulates in these districts does not correspond to the total area of pastures and hayfields. However, in the future it is possible to further increase efficiency in this area through the efficient use of groundwater resources in the region. Currently, there are 453,700 ungulates in $7,339,837$ hectares of pastures in the study area[8]. Taking into account the construction of additional wells for livestock in this livestock area, it can be noted that there is a possibility to feed 3670000 sheep in the area, given that in theory there is one sheep per two hectares. To achieve these desired results, the following measures should be taken:

Table 2

Tomdi and Uchkuduk districts are some indicators related to livestock

\begin{tabular}{|c|c|c|c|c|c|c|c|c|}
\hline \multirow[t]{2}{*}{ Districts } & \multirow{2}{*}{$\begin{array}{l}\text { Land area, } \\
\text { thousand } \\
\text { square kilo- } \\
\text { meters }\end{array}$} & \multirow[b]{2}{*}{$\begin{array}{l}\text { The } \\
\text { share of } \\
\text { districts } \\
\text { in the } \\
\text { republi } \\
\text { can } \\
\text { area }\end{array}$} & \multirow{2}{*}{$\begin{array}{l}\text { Hay and } \\
\text { pastures }\end{array}$} & \multirow{2}{*}{$\begin{array}{l}\text { Numbe } \\
\text { r of } \\
\text { hooves }\end{array}$} & \multirow[b]{2}{*}{$\begin{array}{l}\text { Sheep } \\
\text { and } \\
\text { goats }\end{array}$} & \multirow[b]{2}{*}{\begin{tabular}{|l|} 
Cattle \\
with \\
large \\
horns
\end{tabular}} & \multirow[b]{2}{*}{$\begin{array}{l}\text { Horse } \\
\mathrm{s}\end{array}$} & \multirow[b]{2}{*}{ Camel } \\
\hline & & & & & & & & \\
\hline Tomdi & 42,49 & \multirow[b]{2}{*}{$11 / 5$} & $\begin{array}{l}3577600 \\
(84,2)\end{array}$ & 279,5 & 268,2 & 4,2 & 4,6 & 2,5 \\
\hline Uchkuduk & 46,63 & & $\begin{array}{l}3862237 \\
(79,3 \%)\end{array}$ & 126,3 & 117,0 & 3,4 & 3,8 & 2,1 \\
\hline
\end{tabular}

The table was developed by the author.

- Establishment of irrigation points equipped with a radius of not more than $5 \mathrm{~km}$ from the grazing areas (is one pump per 2,500 hectares);

- Further improvement of pasture infrastructure; -ensure the exchange of pastures;

- pasture reproduction and pasture rehabilitation;

- It is expedient to further improve the existing calendar plan of pasture exchange.

With the implementation of these measures, there will be some significant positive changes in the economic development of the districts, as well as the region.

\section{Conclusion}

In general, it is expedient to further develop the economy in the region, including the comprehensive modernization of the agricultural sector, to pay more attention to their development with the deep use of scientific and technical achievements. Implementation of measures aimed at the introduction of modern and intensive resource-saving agro-technologies, advanced foreign experience in the region; it is necessary to properly feed and maintain livestock in natural pastures, to ensure that the grass load and its normative capacity are adequate, to use alternative, cheaper and more convenient technologies in the preparation of fodder in the conditions of farms specializing in karakul;

References:

[1] Komilova, N.Kh., Hudayberganova, R.T, Murtazaev, I.B., Abdinazarova, H.O., \& 
Madaminov, Z.H. (2019). Economic and Geographic Problems of Improvement of Industrial Sectors and Local Structure of Uzbekistan. Journal of Advanced Research in Law and Economics, 10 ( 6 (44)), 19161928.

[2] Komilova, N. K., Haydarova, Ş. A., Xalmirzaev, A. A., Kurbanov, S. B., \& Rajabov, F. T. (2019). Territorial Structure of Agriculture Development in Uzbekistan in Terms of Economical Geography. Journal of Advanced Research in Law and Economics, $10(8$ (46)), 2364-2372.

[3] Murtazaev I.B. On the issue of developing a strategy for the socio-economic development of the Navoi region // Economy and entrepreneurship. No. 12. Moscow, 2017. -S. 324-326.

[4] Murtazaev I.B.(2018) The question of development of the strategy for socio economic development of the Navoi region. European journal of economics and Management Sciences. №3. 36-40.

[5] Komilova, N.Kh., Mukhammedova, N.J. Abdalova, Z.T., Nazarov, M.I., \& Kurbanov, P.R.(2020). Separate aspects of the demographic situation in Uzbekistan and its assessment in geographical context. International Journal of Psychosocial Rehabilitation. 24(08) 67736792

[6] Komilova, N.K., Mukhammedova, N.J., TOJIEVA, Z.N., Nazarov, M.I., \& Egamberdiyeva, U.T.(2019) Territorial Definitions of Population Mortality in Uzbekistan ASTRA SALVENSIS, YEAR VII, Supplement no. 1, 619-641

[7] Annual statistical collection of Uzbekistan, Tashkent, 2019.

[8] Resolution of the Cabinet of Ministers of the Republic of Uzbekistan No. 689. T. August 19, 2019. 